\section{Pacific Northwest}

National Laboratory

Operated by Battelle for the

U.S. Department of Energy

\title{
Energy Efficiency of the 2003 International Energy Conservation Code in West Virginia
}

\author{
R.G. Lucas
}

December 2006

Prepared for

U.S. Department of Energy

under Contract DE-AC05-76RL01830 


\section{DISCLAIMER}

This report was prepared as an account of work sponsored by an agency of the United States Government. Neither the United States Government nor any agency thereof, nor Battelle Memorial Institute, nor any of their employees, makes any warranty, express or implied, or assumes any legal liability or responsibility for the accuracy, completeness, or usefulness of any information, apparatus, product, or process disclosed, or represents that its use would not infringe privately owned

rights. Reference herein to any specific commercial product, process, or service by trade name, trademark, manufacturer, or otherwise does not necessarily constitute or imply its endorsement, recommendation, or favoring by the United States Government or any agency thereof, or Battelle Memorial Institute. The views and opinions of authors expressed herein do not necessarily state or reflect those of the United States Government or any agency thereof.

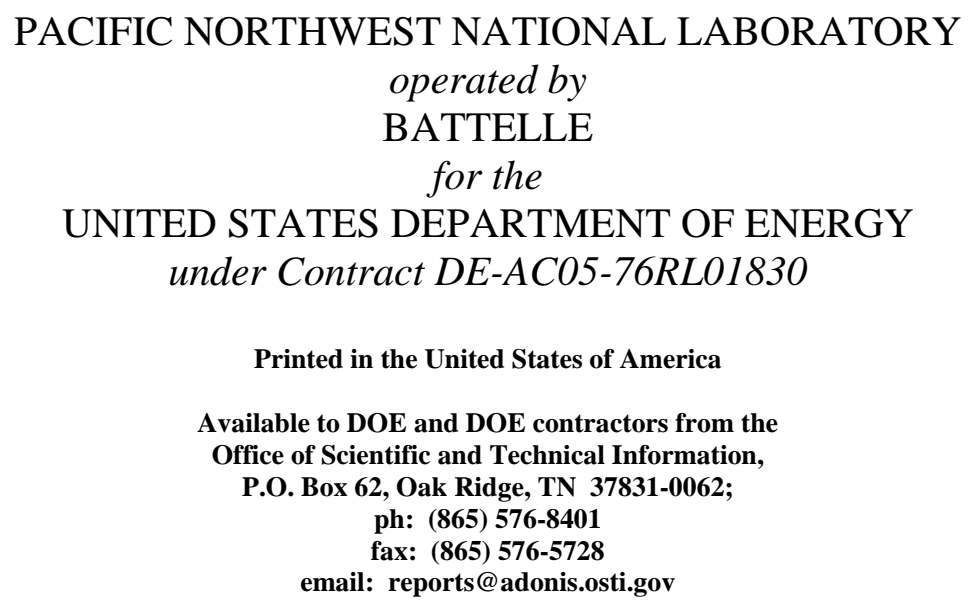

Available to the public from the National Technical Information Service, U.S. Department of Commerce, 5285 Port Royal Rd., Springfield, VA 22161 ph: (800) 553-6847 fax: (703) 605-6900

email: orders@ntis.fedworld.gov online ordering: http://www.ntis.gov/ordering.htm 


\section{Energy Efficiency of the 2003 International Energy Conservation Code in West Virginia}

R.G. Lucas

December 2006

Prepared for

the U.S. Department of Energy

under Contract DE-AC05-76RL01830

Pacific Northwest National Laboratory

Richland, Washington 99352 


\section{Summary}

DOE has requested Pacific Northwest National Laboratory (PNNL) to estimate the energy savings, economic impacts, and pollution reduction from adopting the 2003 International Code Council's (ICC) 2003 International Energy Conservation Code (IECC) (ICC 2003a) as the mandatory residential energy efficiency code in the state of West Virginia. The state currently allows a less stringent replacement option. This report addresses the impacts for low-rise residential buildings only.

The analysis indicates that homes built to meet the IECC requirements will save West Virginia homeowners money by reducing long-term energy costs by far more than the construction-related cost increases. Energy costs will be reduced $16 \%$ to $17 \%$.

Homeowners with a typical mortgage should realize a net positive cash flow within less than a year. Benefit/cost ratios range from 4.3 to 5.2. The analysis also indicates that a significant improvement in pollution reduction can be achieved over time as more and more buildings are built to the code. Construction cost increases and energy savings will vary depending on many factors, including location, fuel prices, house size and characteristics, material and labor costs, and the specific energy efficiency measures used to comply with the 2003 IECC 


\section{Contents}

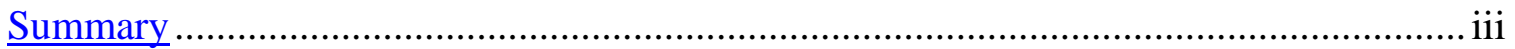

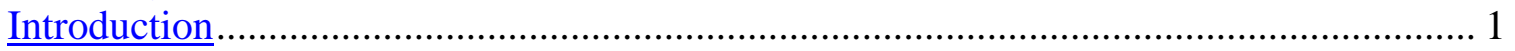

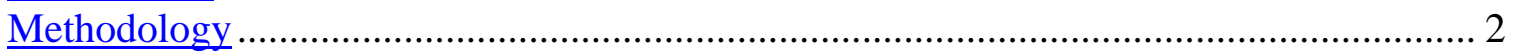

West Virginia Replacement of Chapter 11 of the IRC ................................................ 3

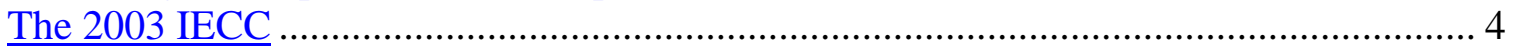

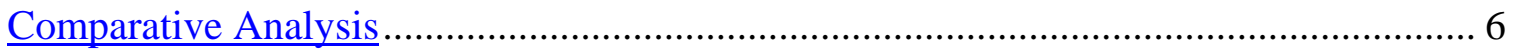

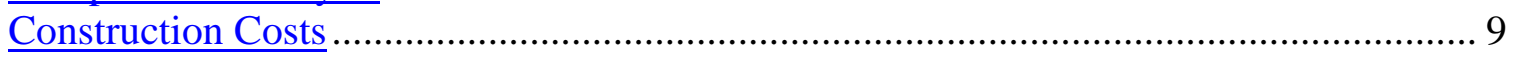

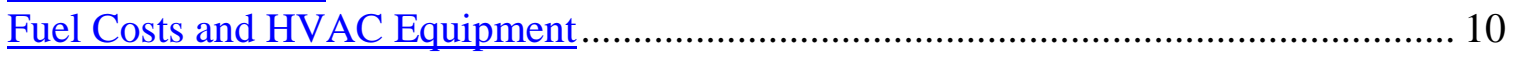

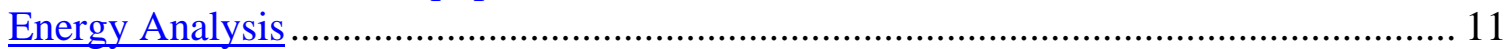

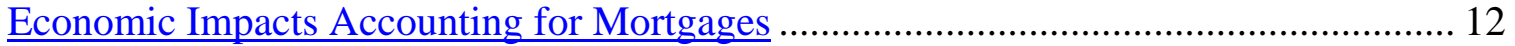

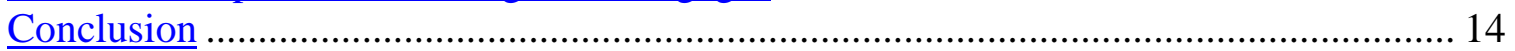

References 


\section{Figures}

Figure 1. West Virginia Replacement Envelope Requirements by Climate...................... 3

Figure 2. IECC Envelope Requirements by Climate (15\% Window Area) ..................... 5

\section{Tables}

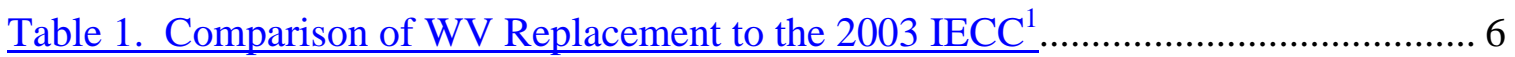

Table 2. 2003 IECC Compliance Measures Using REScheck.......................................... 8

Table 3. Incremental Construction Costs for IECC Energy Efficiency Measures Relative

to the West Virginia Replacement Code............................................................................ 9

Table 4. Annual Heating and Cooling Energy Costs in Charleston ................................ 11

Table 5. Annual Heating and Cooling Energy Costs in Elkins....................................... 11

Table 6. Impacts to Consumers' Cash Flow from Compliance with IECC Accounting for

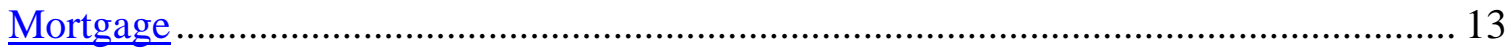




\section{Introduction}

The West Virginia State Building Code ${ }^{1}$ contains two options for energy efficiency requirements in one- and two-family dwellings. One is the IECC (ICC 2003a) (87-44.1.6). The second is a West Virginia developed replacement for Chapter 11 of the ICC International Residential Code (IRC) (ICC 2003b) (87-4-4.1.7). The West Virginia Energy Efficiency Program, West Virginia Development Office, has asked the U.S. Department of Energy (DOE) to compare the energy use and economic impacts resulting from the application of the 2003 IECC code and the IRC code, as amended by West Virginia. The Department's Pacific Northwest National Laboratory (PNNL) compared the energy use from compliance with the 2003 IECC to the West Virginia replacement for Chapter 11 of the IRC, which is referred to as the West Virginia replacement. The West Virginia replacement is less stringent than the 2003 IECC $^{2}$. The results of this analysis are presented below.

\footnotetext{
${ }^{1}$ http://www.wvsos.com/adlaw/rules/verify.asp?TitleSeries=87-04 Title 87, Series 4 of the Code of State Rules.

${ }^{2}$ People will often use the least stringent option available to them in the code to minimize their construction costs. Therefore, although the West Virginia building codes include the 2003 IECC, the requirements in the West Virginia replacement of Chapter 11 of the IRC are assumed to be the minimum code baseline here.
} 


\section{Methodology}

The analysis examined the typical cost and energy savings from the incremental improvements from the West Virginia replacement to the 2003 IECC using computer simulations. Two locations in West Virginia were examined: Charleston and Elkins. These cities represent a climate in the warmer and colder parts of West Virginia, respectively. The house design considered was a $2000 \mathrm{ft}^{2}$ two-story house, $25 \times 40 \mathrm{ft}$, $15 \%$ window-to-wall area ratio, and a full unconditioned basement. Heating with a natural gas furnace and central electric air conditioning were assumed. 


\section{West Virginia Replacement of Chapter 11 of the IRC}

The prescriptive envelope requirements for the West Virginia replacement, that are constant throughout the state, are shown below.

- R-13 above-grade wall insulation

- R-4 slab-on-grade insulation, 2-ft deep

- R-8 crawl space wall insulation (if the crawl space does not have floor insulation)

- R-4 basement wall insulation with depth to approximately $3 \mathrm{ft}$ below grade

- U-0.39 doors with one door exempt

- 6 sq. ft of window area exempt from the U-factor requirements

- Standard air infiltration requirements to seal the building envelope

- R-5 duct insulation

- Ducts outside the building envelope must be sealed by gaskets, mastics, or tapes.

Three building envelope component requirements vary by heating degree-days (HDD), ceilings, windows, and floors. These envelope component requirements, along with the above-grade and basement wall requirements, are shown in Figure 1 below (this map uses average heating degree-days by county).

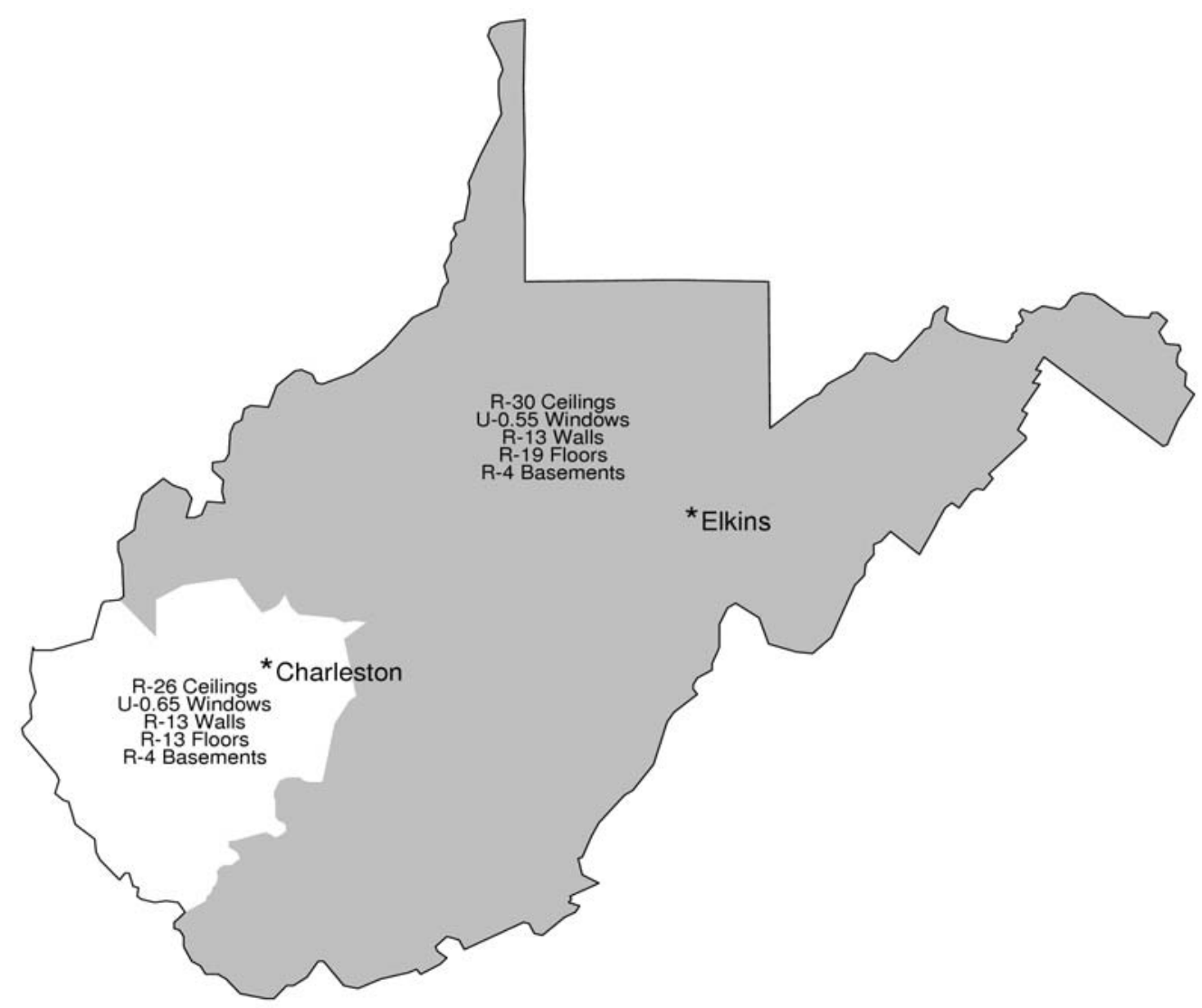

Figure 1. West Virginia Replacement Envelope Requirements by Climate 


\section{The 2003 IECC}

The 2003 IECC has three alternative compliance paths: systems analysis, component performance, and simplified prescriptive requirements. The systems analysis compliance path compares an annual energy analysis of the proposed design to that of a standard design based on criteria in the component performance approach. The proposed design must use the same or less energy than the standard design. The component performance compliance path has a set of figures and tables that set U-factor or R-value requirements for each envelope component as a function of HDD. The simplified prescriptive compliance path has tables of requirements for insulation R-values and window Ufactors.

The envelope requirements in the prescriptive compliance path vary with changes to the window-to-wall area ratio. For example, the prescriptive requirements for a house in Charleston with a window area of $12 \%$ of the wall area have a window U-factor requirement of 0.50 , while a house with a window area of $18 \%$ of the wall area has a window U-factor requirement of 0.37 (see Tables 502.2.4(2) and 502.2.4(4), 2003 IECC).

The prescriptive requirements shown for the IECC in Figure 2 are for a window-to-wall area ratio of $15 \%$. The $15 \%$ area is likely to be a little higher than the average window area in new West Virginia houses (estimated to be between 12 and 14\% on average, although there will a distribution with some houses up to $20 \%$ or more and others down to $10 \%$ or less). Therefore, Figure 2 presents a slightly conservative, more stringent representation of the IECC code envelope requirements. 


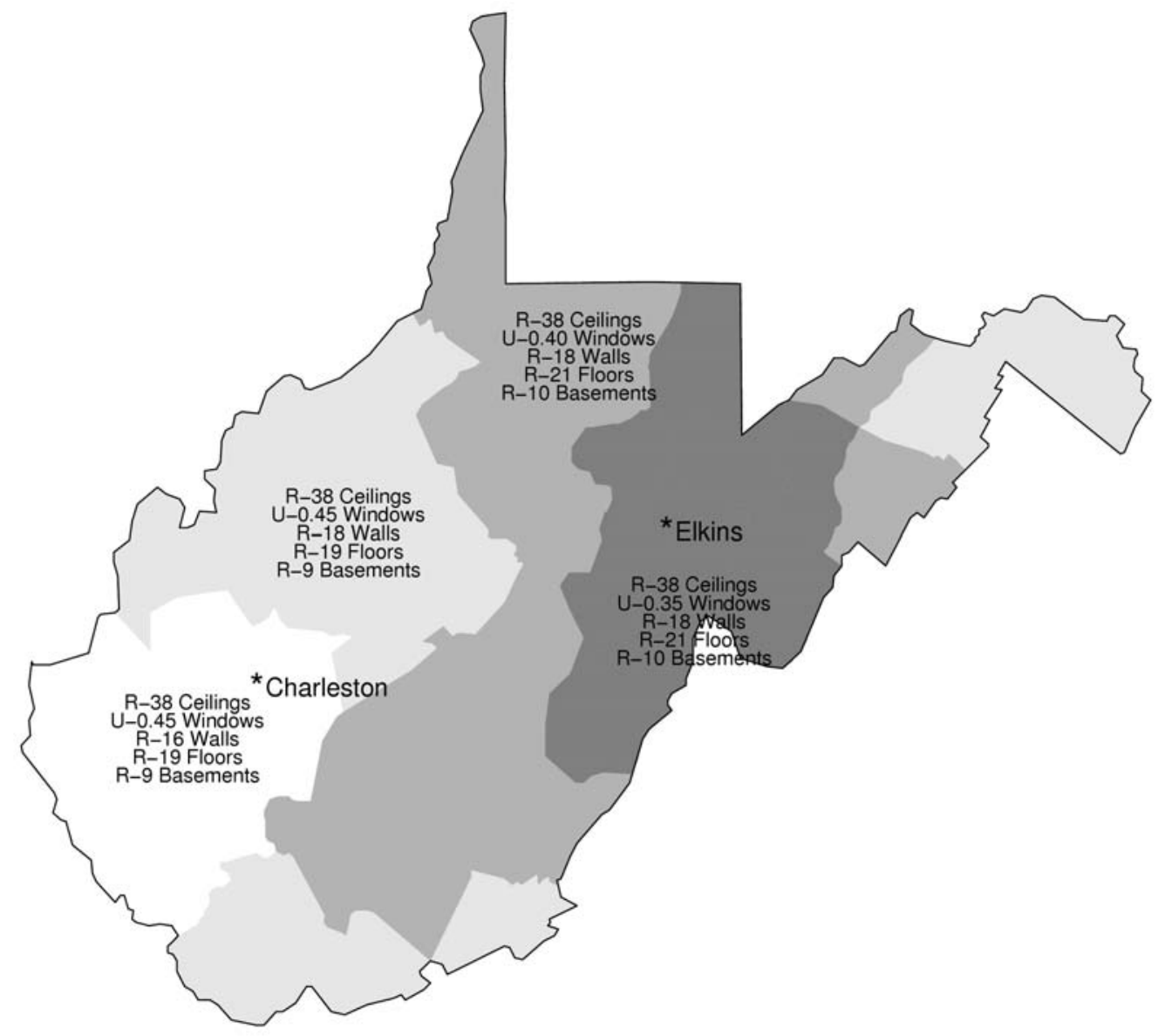

Figure 2. IECC Envelope Requirements by Climate (15\% Window Area) 


\section{Comparative Analysis}

A direct comparison of primary requirements of the West Virginia replacement and the component performance compliance path, at 15\% window-to-wall area ratio, are presented in Table 1.

Table 1. Comparison of WV Replacement to the 2003 IECC $^{1}$

\begin{tabular}{|c|c|c|c|c|c|c|c|c|c|c|}
\hline Code & HDD & Ceiling & $\begin{array}{l}\text { Window/ } \\
\text { Skylight }\end{array}$ & Doors $^{2}$ & $\begin{array}{c}\text { Exterior } \\
\text { Wall }\end{array}$ & Floor & $\begin{array}{c}\text { Basement } \\
\text { Wall }\end{array}$ & $\begin{array}{c}\text { Slab } \\
\text { Peri- } \\
\text { meter }^{3}\end{array}$ & $\begin{array}{l}\text { Crawl } \\
\text { Space } \\
\text { Wall } \\
\end{array}$ & $\begin{array}{c}\text { Ducts } \\
\text { Outside } \\
\text { Envelope }\end{array}$ \\
\hline \multirow{2}{*}{$\begin{array}{l}\text { WV } \\
\text { Replace- } \\
\text { ment }\end{array}$} & $\begin{array}{l}4,500- \\
4,999\end{array}$ & R-26 & $\mathrm{U}-0.65^{4}$ & \multirow{2}{*}{ U-0.39 } & \multirow{2}{*}{ R-13 } & $\mathrm{R}-13$ & \multirow{2}{*}{$\mathrm{R}-4,3 \mathrm{ft} .^{5}$} & \multirow{2}{*}{$\mathrm{R}-4,2 \mathrm{ft}}$. & \multirow{2}{*}{$\mathrm{R}-8$} & \multirow{2}{*}{$\mathrm{R}-5$} \\
\hline & $\begin{array}{l}5,000- \\
6,499\end{array}$ & R-30 & $\mathrm{U}-0.55^{4}$ & & & R-19 & & & & \\
\hline \multirow{4}{*}{$\begin{array}{l}2003 \\
\text { IECC }\end{array}$} & $\begin{array}{c}4,500- \\
4,999\end{array}$ & \multirow{4}{*}{$\mathrm{R}-38$} & \multirow{2}{*}{$\mathrm{U}-0.45^{6}$} & \multirow{4}{*}{ U-0.35 } & R-16 & \multirow{2}{*}{ R-19 } & \multirow{2}{*}{$\mathrm{R}-9^{7}$} & $\mathrm{R}-6,2 \mathrm{ft}$. & R-17 & \multirow{4}{*}{$\begin{array}{l}\text { R-8 } \\
\text { supply }\end{array}$} \\
\hline & $\begin{array}{l}5,000- \\
5,499\end{array}$ & & & & \multirow{3}{*}{$\mathrm{R}-18$} & & & $\mathrm{R}-6,2 \mathrm{ft}$. & R-1/ & \\
\hline & $\begin{array}{l}5,500- \\
5,999\end{array}$ & & $\mathrm{U}-0.40^{6}$ & & & \multirow{2}{*}{$\mathrm{R}-21$} & \multirow{2}{*}{$\mathrm{R}-10^{7}$} & R-9, 2 ft. & $\mathrm{R}-19$ & \\
\hline & $\begin{array}{l}6,000- \\
6,499\end{array}$ & & $\mathrm{U}-0.35^{6}$ & & & & & $\mathrm{R}-9,4 \mathrm{ft}$. & $\mathrm{R}-20$ & \\
\hline $\begin{array}{ll}1 . & \\
2 . & \\
3 . & 1 \\
4 . & 5 \\
5 . & 1 \\
6 . & 1 \\
7 . & \\
\end{array}$ & $\begin{array}{l}\text { teria at } 1 \\
\text { e door is } \\
\text { alue and } \\
\text { square } f \\
\text { a depth } \\
\text { of the } w \\
\text { a depth }\end{array}$ & $\begin{array}{l}\text { \% glazing } \\
\text { xempt in } \\
\text { lepth of i } \\
\text { tt of winc } \\
3 \text { feet be } \\
\text { dow area } \\
10 \text { feet b }\end{array}$ & $\begin{array}{l}\text { rea, Table } 5 \\
\text { th code crit } \\
\text { ulation. } \\
\text { w is exempt } \\
\text { w grade. } \\
\text { s exempt. } \\
\text { ow grade or }\end{array}$ & $\begin{array}{l}2.2 .4(3) \\
\text { ria. } \\
\text { Skylight }\end{array}$ & are require & to be $\mathrm{d}$ & uble-glazed & ad wood, v & yl, or fib & rglass. \\
\hline
\end{tabular}

The IECC has more stringent envelope requirements than the West Virginia replacement. In comparison to the IECC, the replacement code has lower insulation requirements, less stringent window U-factor requirements, and reduced supply duct insulation. These factors are accounted for in the energy analysis below.

The replacement code also differs from the IECC in ways that may further reduce energy efficiency, which are not examined in the energy analysis. Section N1101.4.5 in the West Virginia replacement of the IRC does not prohibit vents in crawl spaces with crawl space wall insulation. Open vents in winter will allow cold air to flow into the crawl space and therefore undercut the benefit of the wall insulation. Occupants may close the vents in the winter, but codes traditionally decline to depend on occupant intervention. The energy efficiency requirements in the IECC do not allow vents if the method of insulating the crawl space is with insulation on the crawl space walls.

Table N1101, note 5 and Section N1101.4.6 of the West Virginia replacement require that basement wall insulation extend down to the frost depth, which will be about $3 \mathrm{ft}$ below grade in West Virginia. The IECC requires basement wall insulation to extend 
down to the basement floor. There will be greater heat loss from the lower area of the basement wall without full basement insulation.

The West Virginia replacement allows heated basements to completely forgo wall insulation if, 1) not more than 12 inches of the top of the wall is above ground, and 2) the gas furnace efficiency is $88 \%$ or higher or the heat pump efficiency (HSPF) is 7.8 or higher. Uninsulated basement walls are permitted even if the basement is a conditioned living space. The Federal manufacturing standard for heat pumps was updated in January 2006. It requires a minimum HSPF of 7.7 for all heat pumps manufactured or imported into the U.S. Therefore, the West Virginia replacement allows basement wall insulation to be eliminated for a tiny improvement in heat pump efficiency. The IECC requires R-9 or R-10 basement wall insulation, depending on location.

No wall insulation for basements that are conditioned living spaces is a major flaw regardless of how efficient the furnace or heat pump is because this allows the top of the wall to be exposed to outdoor air with nothing but highly conductive concrete or masonry. Note that even the West Virginia replacement requires above-grade (excluding basements) walls to have insulation in climates as warm as Miami.

Unlike the IECC, there is no U-factor requirement for skylights in the replacement code. However, skylights must be double-glazed, and cannot be metal frame, so the skylight requirement in the replacement code could be met with a wood (or vinyl) framed unit with a typical U-factor of about 0.50 , compared with an IECC U-factor requirement of U0.35 to U-0.45. Such a unit is reasonably energy efficient.

While the IECC does not have these prescriptive trade-offs, the system performance compliance path allows trade-offs that do not increase the annual energy consumption of the proposed house above that of the standard design. The REScheck software, developed by the U.S. Department of Energy, ${ }^{3}$ allows users to easily examine different energy efficiency measures, under the component performance approach, to determine if they comply with a particular code. The energy efficiency requirements were set in REScheck to comply with the 2003 IECC for the $2000 \mathrm{ft}^{2}$ house examined here. In the case of Charleston, a lower ceiling R-value and wall R-value insulation were used in a trade-off for a better window U-factor and furnace efficiency. In the case of Elkins, lower wall and floor R-values were traded-off for a higher furnace efficiency. The REScheck-compliant packages, shown in Table 2, were then used in the energy analysis.

\footnotetext{
${ }^{3}$ http://www.energycodes.gov/REScheck.
} 
Table 2. 2003 IECC Compliance Measures Using REScheck

\begin{tabular}{|l|l|l|l|l|l|}
\hline & $\begin{array}{l}\text { Ceiling } \\
\text { R-value }\end{array}$ & $\begin{array}{l}\text { Window } \\
\text { U-factor }\end{array}$ & $\begin{array}{l}\text { Wall } \\
\text { R-value }\end{array}$ & $\begin{array}{l}\text { Floor (Over } \\
\text { Unconditioned } \\
\text { Basement) } \\
\text { R-value }\end{array}$ & $\begin{array}{l}\text { Furnace } \\
\text { AFUE }^{(a)}\end{array}$ \\
\hline Charleston & 30 & 0.40 & 13 & 19 & $80 \%$ \\
\hline Elkins & 38 & 0.35 & 13 & 19 & $80 \%$ \\
\hline
\end{tabular}

(a) annual fuel utilization efficiency 


\section{Construction Costs}

This section identifies the construction cost increases for improving from the West Virginia replacement to the 2003 IECC. Floor insulation cost increases from R-13 to R19 were obtained from R.S. Means (2004) and are $\$ 0.16 / \mathrm{ft}^{2}$ for R-19 floor insulation compared to R-13. For ceiling insulation, R.S. Means reports $\$ 0.18 / \mathrm{ft}^{2}$ for the improvement from R-30 to R-38. These costs were used in the analysis.

Improvements to windows needed to achieve U-factors low enough to comply with the IECC are expected to be primarily from the addition of low-E coatings on double-pane windows. A Building America team member estimates typical cost increases of $\$ 300$ for a typical house for windows meeting Energy Star (U-0.35 in cold climates) ratings (Edminster et al. 2000). The Northwest Energy Star Window Project reports an incremental retail cost of $\$ 0.89 / \mathrm{ft}^{2}$ from seven manufacturers to improve windows from U-0.44 to U-0.34 (Quantec 2002). A recent report from California suggests a $\$ 0.15 / \mathrm{ft}^{2}$ incremental cost for manufacturing low-E windows (PGE 2006). A conservatively high cost of $\$ 1 / \mathrm{ft}^{2}$ was assumed for the addition of low-E coatings to a vinyl or wood doublepane window. This improvement is assumed achieve both the U- 0.40 requirement in Charleston and the U-0.35 requirement in Elkins, as numerous low-E window are below U-0.35. Approximately $60 \%$ of new residential windows nationwide are low-E, indicating the cost of this feature is apparently low enough that it is close to becoming standard practice (Door and Window Maker Magazine, April 2005).

A supply duct surface area of $216 \mathrm{ft}^{2}$ and a return duct surface area of $100 \mathrm{ft}^{2}$ in the basement was assumed. The total cost for insulating the ducts to R-5 is $\$ 692$. The 2003 IECC requires R-8 on supply ducts in unconditioned spaces. R.S. Means (2004) reports only an extra 2 cents/ft ${ }^{2}$ in material cost for 1-1/2 in. insulation compared to 1 in. insulation for duct wrap. However, the California Database for Energy Efficient Resources (DEER) (Itron 2005) estimates a higher cost of $\$ 0.68 / \mathrm{ft}^{2}$, or $\$ 147$ for the supply ducts in the basements to increase from R-4.2 to R-8 (R-5 was not included in the California database). This cost is assumed here. Table 3 shows the incremental construction costs assumed in this analysis.

Table 3. Incremental Construction Costs for IECC Energy Efficiency Measures Relative to the West Virginia Replacement Code

\begin{tabular}{|l|l|l|l|l|l|}
\hline & $\begin{array}{l}\text { Ceiling } \\
\text { Insulation }\end{array}$ & $\begin{array}{l}\text { Window } \\
\text { U-factor }\end{array}$ & $\begin{array}{l}\text { Floor (Over } \\
\text { Unconditioned } \\
\text { Basement) } \\
\text { Insulation }\end{array}$ & $\begin{array}{l}\text { Duct } \\
\text { Insulation }\end{array}$ & Total \\
\hline Charleston & 0 & $\$ 332$ & $\$ 160$ & $\$ 147$ & $\$ 639$ \\
\hline Elkins & $\$ 180$ & $\$ 332$ & 0 & $\$ 147$ & $\$ 659$ \\
\hline
\end{tabular}




\section{Fuel Costs and HVAC Equipment}

A natural gas furnace and a central air conditioner are assumed in the analysis. The latest available costs for natural gas and electricity were obtained from the DOE Energy Information Administration. Natural gas prices have increased dramatically in the past 5 years, and peaked above $\$ 15$ per thousand cubic feet (approximately equal to a million Btus) in West Virginia for the residential market last winter (DOE/EIA http://tonto.eia.doe.gov/dnav/ng/ng_pri_sum_dcu_SWV_m.htm). Recent (September 2006) DOE fuel price Short Term Energy Outlook projections (DOE/EIA 2006 http://www.eia.doe.gov/emeu/steo/pub/8ctab.html) estimate residential natural gas prices in the South Atlantic region (which West Virginia is in) to stay at or above \$15 per thousand cubic feet for the next few years during the winter. A natural gas cost of \$15/MBtu was assumed in this analysis. The electricity price for air conditioning was assumed to be 6.41 cents/kWh based on June 2006 prices in West Virginia (DOE/EIA http://www.eia.doe.gov/cneaf/electricity/epm/table5_6_a.html). 


\section{Energy Analysis}

The EnergyGauge simulation tool (Florida Solar Energy Center) was used to estimate the savings from improving energy efficiency of a home designed to the replacement code to instead comply with the 2003 IECC (using the measures in Table 2). EnergyGauge utilizes the DOE-2 simulation model that estimates the building energy use for all 8760 hours in a year. Tables 4 and 5 show the comparative energy costs and saving differential for the home in Charleston and Elkins. These tables include space heating and air conditioning only. Note that this energy analysis is based on the exact prescriptive requirements discussed above. Actual measures installed in homes may exceed these requirements in some cases (notably window U-factors in the replacement code).

Table 4. Annual Heating and Cooling Energy Costs in Charleston

\begin{tabular}{|l|c|c|}
\hline & 2003 IECC & $\begin{array}{c}\text { Replacement } \\
\text { Code }\end{array}$ \\
\hline Heating & $\$ 704$ & $\$ 867$ \\
\hline Cooling & $\$ 92$ & $\$ 87$ \\
\hline Total & $\$ 796$ & $\$ 954$ \\
\hline $\begin{array}{l}\text { Energy cost savings of } \\
\text { IECC }\end{array}$ & \multicolumn{2}{|c|}{$\$ 158$ or $17 \%$} \\
\hline
\end{tabular}

Table 5. Annual Heating and Cooling Energy Costs in Elkins

\begin{tabular}{|l|c|c|}
\hline & 2000 IECC & $\begin{array}{c}\text { Replacement } \\
\text { Code }\end{array}$ \\
\hline Heating & $\$ 963$ & $\$ 1160$ \\
\hline Cooling & $\$ 36$ & $\$ 33$ \\
\hline Total & $\$ 999$ & $\$ 1193$ \\
\hline $\begin{array}{l}\text { Energy cost savings of } \\
\text { IECC }\end{array}$ & \multicolumn{2}{|c|}{$\$ 194$ or $16 \%$} \\
\hline
\end{tabular}




\section{Economic Impacts Accounting for Mortgages}

Because most houses are financed, consumers will be very interested in the financial impacts of buying a home that complies with the 2003 IECC requirements. Mortgages spread the payment for the cost of a house over a long period of time. In this analysis, a fixed-rate mortgage was assumed. It was also assumed that homebuyers will deduct the interest portion of the payments from their income taxes.

The financial and economic parameters required for input to this analysis are summarized below. These parameters are used to calculate the costs and benefits of increased energy efficiency from the homeowner's perspective. A relatively low down payment and a moderate Federal income tax rate were selected.

- New-home mortgage parameters:

- $\quad 7.0 \%$ mortgage interest rate (fixed rate)

- points and loan fees equal to $1.6 \%$ of the mortgage amount

- 30-year loan term

- $10 \%$ down payment.

- Other rates and economic parameters:

- $7 \%$ nominal discount rate

- $28 \%$ marginal Federal income tax

- $1.2 \%$ property tax

- $3 \%$ nominal inflation for fuel prices

- 30-year analysis period, no residual/salvage value.

Table 6 shows the impacts to consumers' cash flow resulting from IECC compliance. The up-front costs include the down payment, points, and loan fees. The savings from income tax deductions for the mortgage interest will slowly decrease over time. The annual values shown in the table are for the first year. Table 6 also includes increases in annual property taxes because of the higher assessed house values. The net annual cash flow includes energy costs, mortgage payments, mortgage tax deductions, and property taxes but not the up-front costs. 
Table 6. Impacts to Consumers' Cash Flow from Compliance with IECC Accounting for Mortgage

\begin{tabular}{|l|l|l|}
\hline & Charleston & \multicolumn{1}{|c|}{ Elkins } \\
\hline \hline Up-Front Costs & $\$ 72$ & $\$ 74$ \\
\hline $\begin{array}{l}\text { Annual Energy } \\
\text { Savings }\end{array}$ & $\$ 158$ & $\$ 194$ \\
\hline $\begin{array}{l}\text { Annual } \\
\text { Mortgage } \\
\text { Increase }\end{array}$ & $\$ 48$ & $\$ 49$ \\
\hline $\begin{array}{l}\text { Annual Income } \\
\text { Tax Deduction } \\
\text { Increase }\end{array}$ & $\$ 12$ & $\$ 12$ \\
\hline $\begin{array}{l}\text { Annual Property } \\
\text { Tax Increase }\end{array}$ & $\$ 6$ & $\$ 6$ \\
\hline $\begin{array}{l}\text { Net Annual Cash } \\
\text { Flow Savings } \\
\text { (excluding up- } \\
\text { front costs) }\end{array}$ & $\$ 121$ & $\$ 157$ \\
\hline $\begin{array}{l}\text { Benefit/Cost } \\
\text { Ratio }\end{array}$ & 4.3 & 5.2 \\
\hline $\begin{array}{l}\text { Net Present } \\
\text { Value Savings }\end{array}$ & $\$ 2771$ & $\$ 3406$ \\
\hline $\begin{array}{l}\text { Time to Net } \\
\text { Positive Cash } \\
\text { Flow }\end{array}$ & Under 1 & Under 1 \\
\hline
\end{tabular}




\section{Conclusion}

In almost all respects, the West Virginia replacement is less stringent than the 2003

IECC. This includes less stringent envelope and duct insulation levels; window, door and skylight U-factors; crawl space wall insulation; and the trade-off that allows a heated basement to be uninsulated. Building a home to the requirements of the 2003 IECC is estimated to reduce energy use from space heating and air conditioning by between $16 \%$ and $17 \%$ in typical new homes in West Virginia, compared to the minimum requirements of the replacement code. Accounting for the impacts of a typical mortgage, the home buyer will begin to realize a net savings in less than 1 year.

A homeowner will pay between $\$ 150$ and $\$ 200$ more per year in energy costs for a home built to the West Virginia replacement code compared to the a home built to the IECC. 


\section{References}

Door and Window Maker Magazine, April 2005:

http://www.usglassmag.com/Door_and_Window_Maker/Backissues/April\%202005/

Wealth\%20of\%20Knowledge.htm

Edminster, A. V., B. Pettit, K. Ueno, S. Menegus, and S. Baczek. 2000. "Case Studies in Resource Efficient Residential Building: The Building America Program.” In

Proceedings for the 2000 ACEEE Summer Study, vol. 2, p. 79. American Council for an Energy-Efficient Economy, Washington, D.C.

International Code Council (ICC). 2003a. 2003 International Energy Conservation Code. Falls Church, Virginia.

International Code Council (ICC). 2003b. 2003 International Residential Code. Falls Church, Virginia.

Itron. 2005. 2004/2005 Database for Energy Efficient Resources Update Report. http://eega.cpuc.ca.gov/deer/

Pacific Gas and Electric. 2006. Case Study for Residential Windows. http://www.energy.ca.gov/title24/2008standards/documents/2006-0518 workshop/2006-05-16 RES WINDOWS.PDF

Quantec. 2002. Market Progress Evaluation Report for the Energy Star Windows Project. Northwest Energy Efficiency Alliance, Portland, Oregon.

R. S. Means Company, Inc. (Means). 2004. Means Residential Cost Data--2005, 24th Annual Edition. Kingston, Massachusetts.

Sherman, M. H., I. S. Walker, and D. J. Dickerhoff. 2000. "Stopping Duct Quacks: Longevity of Residential Duct Sealants.” In Proceedings for the 2000 ACEEE Summer Study, vol. 2, p. 79. American Council for an Energy-Efficient Economy, Washington, D.C.

U.S. Department of Energy, Energy Information Administration. 2006.

http://www.eia.doe.gov/cneaf/electricity/epm/table5_6_a.html http://tonto.eia.doe.gov/dnav/ng/ng_pri_sum_dcu_SWV_m.htm http://www.eia.doe.gov/emeu/steo/pub/8ctab.html 